\title{
Emergence of Venice during the Pleistocene
}

\author{
Dennis V. Kent ${ }^{\mathrm{a}, \mathrm{b}, *}$, Domenico Rio ${ }^{\mathrm{c}}$, Francesco Massari ${ }^{\mathrm{c}}$, George Kukla ${ }^{\mathrm{b}}$, Luca Lanci ${ }^{\mathrm{a}}$ \\ ${ }^{a}$ Department of Geological Sciences, Rutgers University, Piscataway, NJ 08854, USA \\ ${ }^{\mathrm{b}}$ Lamont-Doherty Earth Observatory, Palisades, NY 10964, USA \\ ' Dipartimento di Geologia, Universita' di Padova, Via Giotto 1, 35137 Padova, Italy
}

Received 1 May 2001; accepted 29 September 2001

\begin{abstract}
The Pleistocene history of sea-level change for the Venice region was reconstructed using an integrated magneto-bio-cyclostratigraphy of lithofacies and a published palynofloral analysis of continuously cored sediments in a 950-meter-deep drill core. The basin in which the Venice region is located collapsed at $\sim 1.8$ Ma with slow sediment accumulation in the deeper-water starved basin during most of the Matuyama polarity chron but shoaled rapidly in the early and middle Brunhes in response to a major phase of deltaic progradation. The initial transition to continental sediments occurred during a prominent glacioeustatic low-stand that is likely to be MIS $12(\sim 0.43 \mathrm{Ma})$ but could be as young as MIS $8(\sim 0.25 \mathrm{Ma})$. The Venice area oscillated from below sea level during subsequent major glacioeustatic high-stands to becoming increasingly emergent during major low-stands as the basin continued to fill with marine and continental sediments. Some parts of the Venice area are now emergent for the first time during a glacioeustatic high-stand (i.e., MIS 1 or the Holocene). The total long-term subsidence rate estimated from the VENICE-1 record is less than $0.5 \mathrm{~mm} / \mathrm{yr}$, considerably slower than estimates for the Holocene and especially the modern anthropogenic period. (C) 2002 Elsevier Science Ltd. All rights reserved.
\end{abstract}

\section{Introduction}

In response to concern about the accelerated subsidence of Venice in the 1950s and 1960s linked to withdrawal of ground water, a deep test bore (VE-1) was drilled in 1971 by the Consiglio Nazionale delle Richerche (CNR) of Italy on man-made Isola Nuova del Tronchetto with a present ground elevation of $2 \mathrm{~m}$ (Fig. 1). VE-1 was cored from $60 \mathrm{~m}$ to a total depth of $950 \mathrm{~m}$ with about $90 \%$ recovery (CNR, 1971). The uppermost part of the section was recovered in a parallel well (VE-1 BIS) drilled in 1972 to a total depth of $120 \mathrm{~m}$ at a site located about $30 \mathrm{~m}$ from VE-1 well (Favero et al., 1973). The linked composite section of the two cores is referred to here as VENICE-1. Although depths are quoted as originally marked for each core, it should be recognized that depths for VE-1 were measured with respect to the drilling rotary table which was $3.2 \mathrm{~m}$ above the ground reference level for VE-1 BIS.
The sediment cores have been sampled on various occasions but are still largely intact and stored as boxed full-round segments at the CNR core repository at Palazzo Papadopoli in Venice. Previous work on VENICE-1 included a comprehensive site report with lithologic descriptions and well logs (CNR, 1971; Favero et al., 1973), analysis of organic carbon (Bellet et al., 1982), radiocarbon dating (Bortolami et al., 1977, 1985), and pollen analysis (Mullenders et al., 1996). The main characteristics of this and other cores from the Venice region have been summarized by Pirazzoli (1977). Here we provide an integrated analysis of subsidence and sea level changes in Venice during the Pleistocene from VENICE-1 based on new data on nannofossil biostratigraphy, paleomagnetic polarity stratigraphy, magnetic susceptibility variations, and sedimentologic facies interpretations.

\section{Lithofacies and chronostratigraphy}

The Venice area is located at the northern end of the Adriatic Sea in a foreland setting between the eastern Southern Alps and the Apennine chain. These mountain

\footnotetext{
*Corresponding author. Department of Geological Sciences, Rutgers University, Piscataway, NJ 08854, USA. Tel. : + 1-845-365-8544; fax: + 1-845-365-8158.

E-mail address:dvk@rci.rutgers.edu (D.V. Kent).
} 


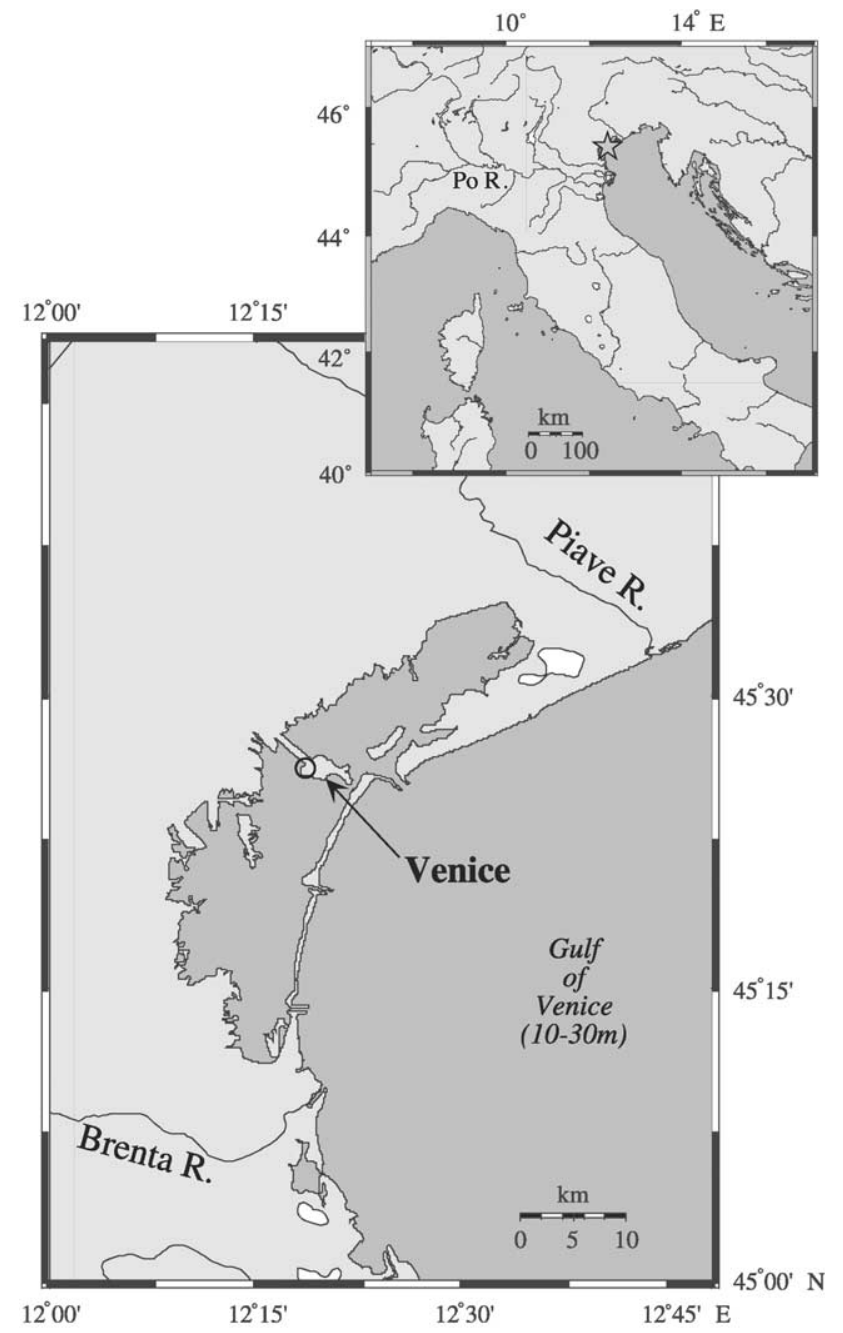

Fig. 1. Sketch map of Venice lagoon at the head of the Adriatic Sea and the location of the VENICE-1 core hole.

belts were affected by thrust emplacement during the Pliocene (Boccaletti et al., 1990). This tectonic activity may have been responsible for the unconformity at $813 \mathrm{~m}$ which separates shallow-water shelf facies (Unit V) of Pliocene age from deeper water, sapropel-bearing sediments (Unit IV) of Early Pleistocene age according to nannofossils (Fig. 2). This fine-grained facies extends to about $768 \mathrm{~m}$. Alternations of more sandy slope and channel facies occur to about $541 \mathrm{~m}$ (Unit III), followed by a thick sand-dominated deltaic facies (to $436 \mathrm{~m}$ ) and then a shelf facies to $289 \mathrm{~m}$ (Unit II) where continental sediments first appear. The upper $289 \mathrm{~m}$ of the succession (Unit I) consists of continental floodplain, marsh and locally eolian facies, corresponding to sea-level lowstands, alternating with marine shelf and shoreface facies of sea-level high-stands. Pollen analysis shows that the low-stands are generally associated with cold (glacial and interstadial) assemblages (Mullenders et al., 1996). There are six prominent sea-level transgressions where continental sediments are overlain by shoreface and shelf marine deposits; these surfaces are labeled tr.1 to tr. 6 and occur at 10.5, 79, 136, 152, 202, and $262 \mathrm{~m}$, respectively.

The common presence of the pollen of Taxodiaceae indicates that the oldest cored section is Pliocene in age (Mullenders et al., 1996). The sapropel-bearing sediments of Unit IV contain rare specimens of the benthic foraminifer Articulina tubulosa which would be indicative of water depths greater than about $500 \mathrm{~m}$ (Parker, 1958). Planktonic foraminifera and nannofossils also occur in this interval and provide a well controlled biochronology ranging from the lowest occurrence (LO) of Gephyrocapsa oceanica s.1. at $809 \mathrm{~m}$ to the Gephyrocapsa sp. 3 LO at $755.8 \mathrm{~m}$, which have a first appearance datum (FAD) estimated at 1.71 and $0.96 \mathrm{Ma}$, respectively (Rio et al., 1997). Most of the succeeding marine deposits of Units III and II are virtually barren. The notable exception is a relatively thin, massive muddy interval between 541 and $575 \mathrm{~m}$ at the top of Unit III where sapropels VS01 and VS02 bracket the highest occurrence (HO) of Gephyrocapsa sp. 3 at $571.5 \mathrm{~m}$ and the Pseudoemiliania lacunosa $\mathrm{HO}$ at $562.4 \mathrm{~m}$. The last appearance datums (LADs) of these species have been tied to astronomically dated Marine Isotope Stages (MIS) and eastern Mediterranean sapropels and have estimated ages of 0.58 and $0.44 \mathrm{Ma}$, respectively (Langereis et al., 1997). In the section above $289 \mathrm{~m}$, where continental and essentially barren shallow-marine beds alternate, fossil pollen assemblages in several key intervals can be correlated with varying degrees of certainty with standard continental stages (Mullenders et al., 1996), as discussed below.

A magnetic polarity stratigraphy was delineated based on consistent thermal demagnetization results from 106 samples (out of 117 samples taken) from cohesive marine sediments oriented with respect to vertical. The upper $\sim 250 \mathrm{~m}$ of the core tended to be sandy and friable and was not sampled. Standard paleomagnetic procedures (principal component analysis of 10 -step thermal demagnetization data from $100^{\circ} \mathrm{C}$ to $600^{\circ} \mathrm{C}$ acquired using a $2 \mathrm{G}$ cryogenic rock magnetometer in a shielded room) were used to recover a characteristic magnetization usually from $350^{\circ} \mathrm{C}$ to $525^{\circ} \mathrm{C}$. IRM acquisition and thermal demagnetization experiments (Lowrie, 1990) indicate that magnetite is an important remanence carrier although the presence of a magnetic sulfide, which is usually a carrier of secondary magnetizations, is also apparent in the more organic rich (Bellet et al., 1982) deltaic facies and near the sapropels.

Biostratigraphic constraints indicate that the upper interval of predominantly positive inclinations (normal polarity) to $727.8 \mathrm{~m}$ is of Brunhes age and that the underlying predominantly reverse polarity interval to at least the unconformity at $813 \mathrm{~m}$ is of Matuyama age (Fig. 2). There is an additional $71 \mathrm{~m}$ of section with 


\section{Magnetic Magnetic GPTS Polarity Inclination \\ Magnetic Susceptibility}

8

$\sum_{\substack{0 \\ \hline}}^{\frac{\pi}{8}}$

0

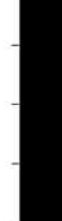

0.5

0.5 C1n
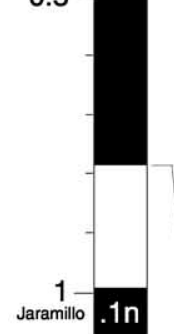

Cobb Mt $-\frac{}{1.5-} \mathrm{C} 1 \mathrm{r}$
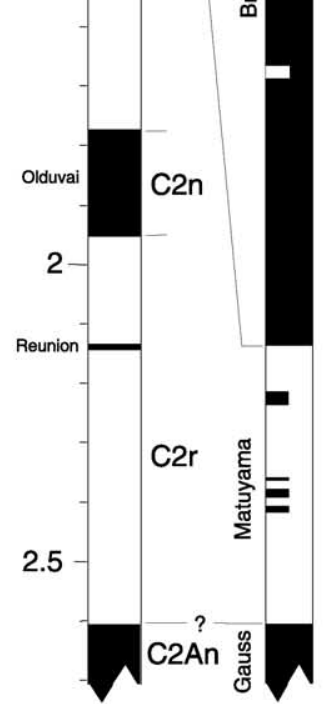

$$
-90^{\circ}
$$
$0^{\circ} \quad 90^{\circ}$

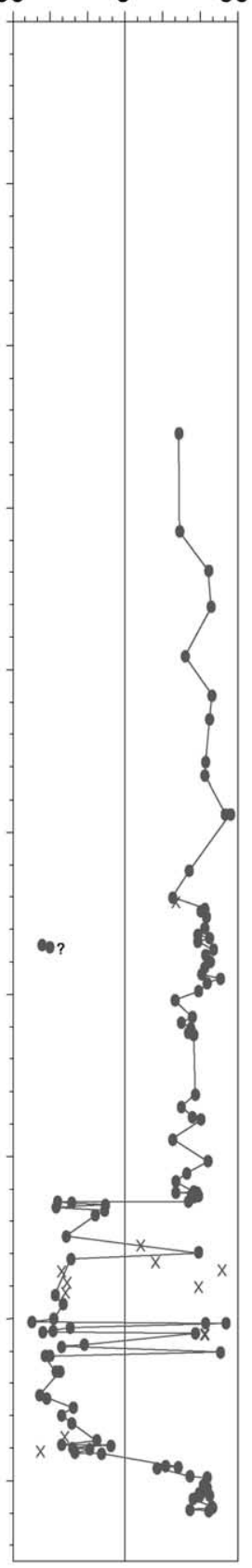

0
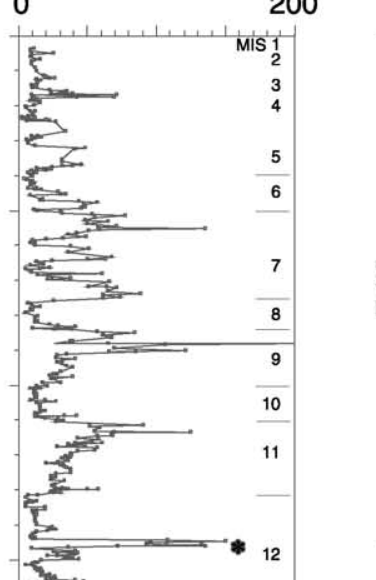

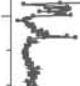
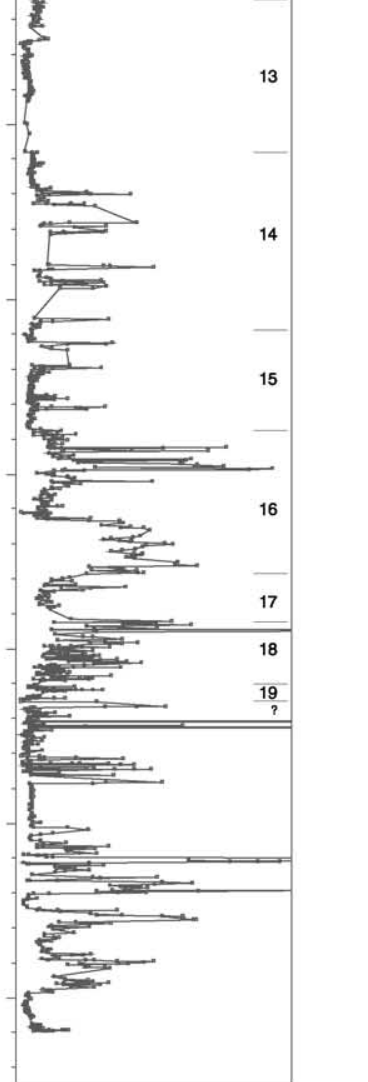

Sediment Facies

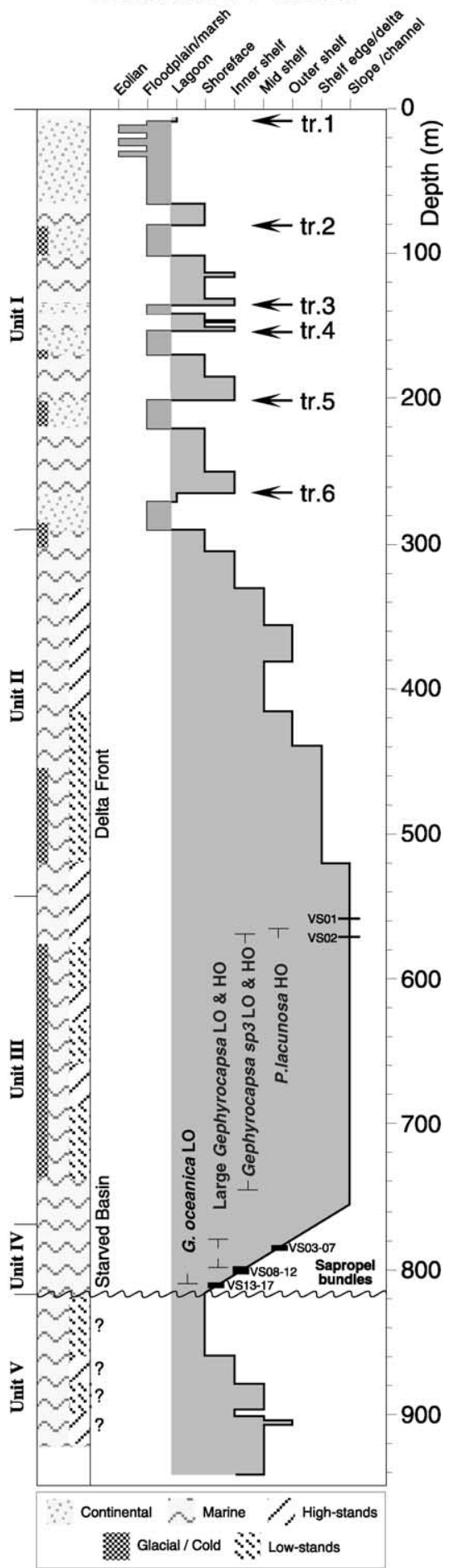

Fig. 2. Magnetic polarity stratigraphy, magnetic susceptibility, sediment facies, and calcareous plankton biostratigraphy for composite section of VENICE-1 core.

predominantly reverse polarity below the stratigraphic break and then a $25-\mathrm{m}$-thick section of normal polarity from $887.2 \mathrm{~m}$ to the base of the measured section. Isolated samples with inclinations of opposite sign within these major magnetozones may represent very short polarity intervals (e.g., Langereis et al., 1997) or more conservatively, reflect unresolved overprints or inverted core segments and are thus of tenuous stratigraphic significance. The polarity change at $887.2 \mathrm{~m}$ occurs almost $80 \mathrm{~m}$ below the G. oceanica s.l. 
LO at $809.1 \mathrm{~m}$, a taxon whose FAD (1.71 Ma; Rio et al., 1997) closely follows the end of the Olduvai Normal Polarity Subchron (C2n: 1.77-1.86 Ma; Cande and Kent, 1995). The reverse polarity interval between 813 and $887.2 \mathrm{~m}$ therefore should represent the lower Matuyama. According to this interpretation, the Olduvai is missing within the hiatus at $813 \mathrm{~m}$ and the change to normal polarity at $887.2 \mathrm{~m}$ represents the $2.58 \mathrm{Ma}$ Matuyama/Gauss (Chron $\mathrm{C} 2 \mathrm{r} / 2 \mathrm{An}$ ) boundary. A less likely alternative is that the lower normal polarity interval corresponds to an extremely expanded section of the very short ( $\sim 10 \mathrm{Kyr})$ Reunion Subchron $(\mathrm{C} 2 \mathrm{r} .1 \mathrm{n}$ : 2.14-2.15 Ma).

Magnetic susceptibility variations are mainly due to changes in concentration or sometimes quality of the magnetic mineral fraction and have proven to be sensitive indicators of paleoenvironmental change in both continental and marine settings (e.g., Robinson, 1986; Kukla et al., 1988). In VENICE-1, magnetic susceptibility was measured with a Bartington susceptometer and contact sensor at approximately $10 \mathrm{~cm}$ intervals on the recovered core. Comparison of susceptibility and sedimentologic logs indicates that high susceptibilities generally correspond to sandy shoreface facies (Fig. 2). In the upper $289 \mathrm{~m}$ of section, complementary intervals with low susceptibility correspond to continental sediments of sea-level low-stands. In the underlying entirely marine section, however, low susceptibilities generally correspond to the finer-grained intervals denoting sea-level high-stands. The transitional susceptibility peak at $289 \mathrm{~m}$ can be understood as a concatenation of the initial increase of susceptibilities associated with the beginning of a marine regression and the immediate decrease of susceptibilities associated with emergence to continental sedimentation.

\section{Sediment accumulation rates}

An age-depth plot shows the evolution in sediment accumulation for the Venice area since the Late Pliocene (Fig. 3; Table 1). The section of shallow-water sediments below the unconformity at $813 \mathrm{~m}$ is assumed to have accumulated at rates of roughly $500 \mathrm{~m} / \mathrm{m} . \mathrm{y}$., based on the occurrence of two or three magnetic susceptibility variations which could represent precession or obliquity Milankovitch climate cycles in the lowermost Matuyama. The unconformity at $813 \mathrm{~m}$ is evidently a record of a Late Pliocene (Gelasian) base-level change (Massari et al., in preparation) and encompassed an interval of about $0.6 \mathrm{~m}$.y. which included the Olduvai. Deeperwater sedimentation commenced after the unconformity and was characterized by low accumulation rates in the middle to late Matuyama $(\sim 60 \mathrm{~m} / \mathrm{m} . \mathrm{y}$. from $\sim 1.8$ to $0.78 \mathrm{Ma}$ ). This resulted in a starved basin in which sapropels, calcareous nannofossils and planktonic for- aminifera were preserved. Sedimentation under shallowing but fluctuating marine conditions continued into the early part of the Brunhes when the more sandy slope and channel facies of Unit III accumulated at rates greater than $700 \mathrm{~m} / \mathrm{m} . \mathrm{y}$. on average. This is based on the $0.783 \mathrm{Ma}$ Brunhes/Matuyama boundary at $727.8 \mathrm{~m}$ and the $0.57 \mathrm{Ma}$ Gephyrocapsa sp. $3 \mathrm{LAD}$ at $571.5 \mathrm{~m}$ which is within a few meters above sapropel VS 02 in the restricted muddy interval toward the top of Unit III. Given the available magnetostratigraphic and biostratigraphic constraints in VENICE-1, sapropel VS02 is likely to be the temporal equivalent of $\mathrm{Sb}$, the first (oldest) sapropel recognized in the Brunhes in the eastern Mediterranean with an estimated (astronomical) age of 0.597 Ma (Langereis et al., 1997).

Two alternative age models are considered for the section above sapropel VS02. Age Model 1 equates sapropel VS01 to the next sapropel in the eastern Mediterranean succession, Sa, with an estimated age of $0.529 \mathrm{Ma}$ (Langereis et al., 1997). This would indicate a reduction of sediment accumulation rates in the muddy interval to about $200 \mathrm{~m} / \mathrm{m}$.y. Age Model 2 assumes that the P. lacunosa $\mathrm{HO}$ at $562.4 \mathrm{~m}$ represents its LAD at $0.44 \mathrm{Ma}$ so that the overlying sapropel VS01 would presumably represent sapropel S11, with an age of $0.407 \mathrm{Ma}$ (Langereis et al., 1997). This would imply that the equivalents of sapropels Sa and S12 of the eastern Mediterranean standard succession are missing in a cryptic hiatus of about $0.1 \mathrm{~m} . \mathrm{y}$. duration.

In either age model, rapid sedimentation ensued with the deltaic and shelf facies that nearly filled the basin and allowed continental sediments to be deposited for the first time at $289 \mathrm{~m}$. This initial interval of continental deposition contains the first truly glacial pollen assemblage in the VENICE-1 core (Mullenders et al., 1996) and was most probably deposited during one of the major glacioeustatic low-stands of the Late Pleistocene. Immediately overlying these continental sediments is a major transgressive surface (tr.6) at $262 \mathrm{~m}$ and marine sediments that contain a very well-developed interglacial pollen assemblage, including a very high abundance of Pterocarya (Mullenders et al., 1996). In northern and central Europe, Pterocarya is a characteristic species of the Holsteinian interglacial (Zagwijn, 1989; de Beaulieu et al., 1994) which is usually correlated with MIS 11 (Urban, 1992; Reille and de Beaulieu, 1995), although in some southern European localities, such as Valle di Castiglione near Rome, Pterocarya has been found in sediments correlated to be as young as MIS 7 (Follieri et al., 1988; Tzedakis et al., 1997; Reille et al., 1998). Age Model 1 allows the correlation of tr.6 with the MIS12/11 glacioeustatic transgression, whereby the first continental sediments are associated with MIS 12 and the immediately overlying Pterocarya-bearing interglacial deposits correspond to MIS 11 . This model would imply a very high sediment accumulation rate of more than 


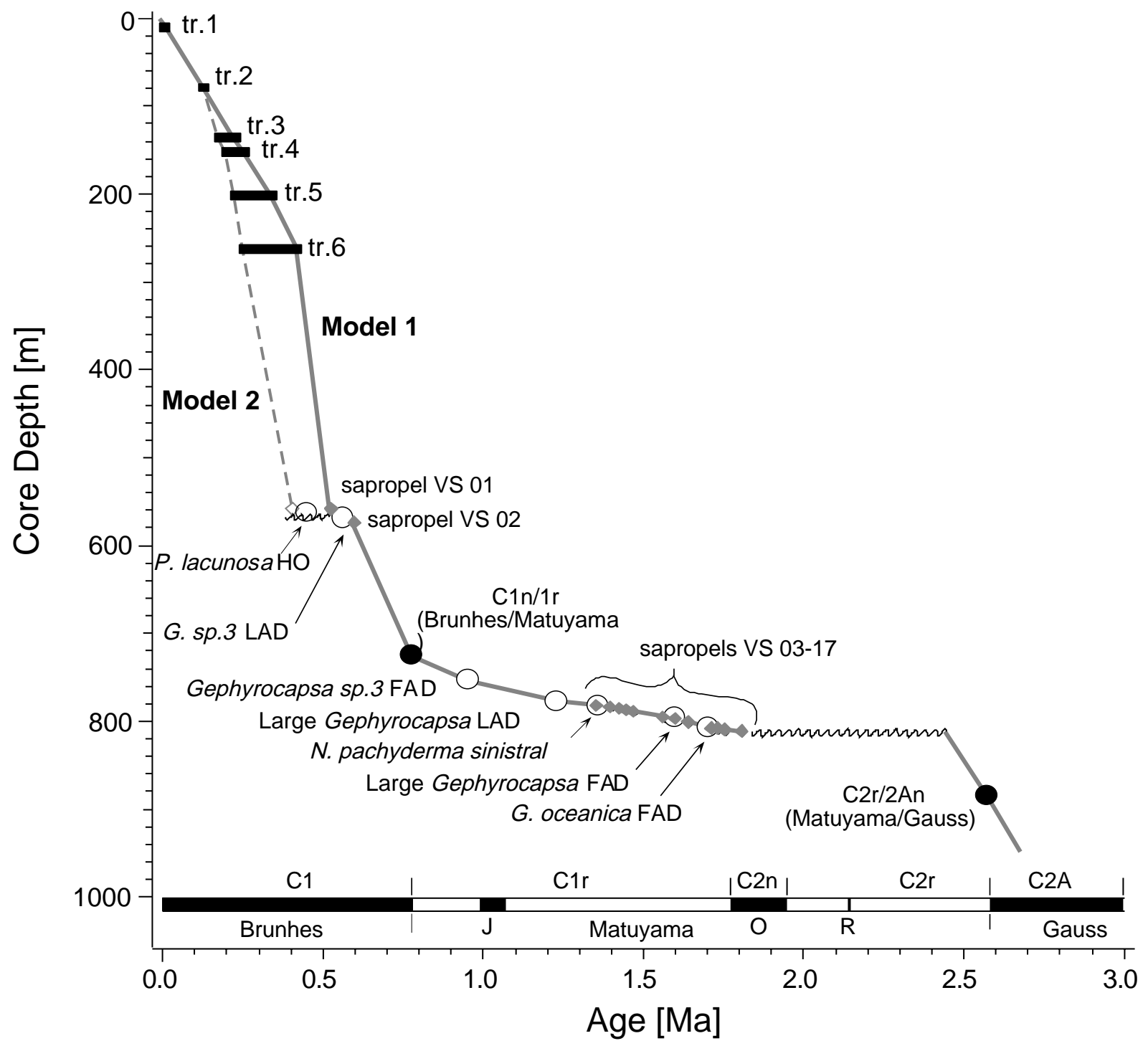

Fig. 3. Depth versus age plot of chronostratigraphic control points for VENICE-1. Age Model 1 (solid line) equates sapropel VS 01 with Mediterranean sapropel Sa (0.529 Ma; Langereis et al., 1997) and transgressive surface tr.6 with MIS 11/12. Age Model 2 (dashed line) assumes that the $P$. lacunosa $\mathrm{HO}$ is its LAD at $0.44 \mathrm{Ma}$. The overlying sapropel VS 01 would thus represent Mediterranean sapropel S11 (0.407 Ma) after a cryptic hiatus and tr.6 would be associated with MIS 7/8. Transgression surfaces tr.1 to tr.6 are shown by filled bars extended over range of likely ages.

$2300 \mathrm{~m} / \mathrm{m} . \mathrm{y}$. for the $\sim 270$-m-thick Unit II. Age Model 2 would suggest a correlation to the MIS 8/7 glacioeustatic transgression as the youngest likely age for tr.6. This model would result in a somewhat reduced sediment accumulation rate of about $1700 \mathrm{~m} / \mathrm{m} . \mathrm{y}$. for Unit II.

\section{Long-term subsidence rate}

A more comprehensive correlation of the succeeding alternations of marine and continental deposits requires that the contributions of eustacy, isostacy, sediment compaction and tectonics be taken into account. A reference glacioeustatic curve was constructed by scaling the astronomically-calibrated ODP677/SPECMAP benthic oxygen isotope record (Shackleton, 1995) to the $120 \mathrm{~m}$ glacioeustatic decrease at the last glacial maximum (LGM) based on the Barbados coral record (Fairbanks, 1989) (Fig. 4a). To account for the effect of isostatic loading, a simple Airy compensation model was used which shows that the sediment should have caused subsidence equivalent to about $1 / 3$ of the sediment thickness (e.g., Sclater and Christie, 1980). Any residual long-term subsidence can be attributed to some combination of sediment compaction and tectonics and must be determined empirically.

Prior to the major $120 \mathrm{~m}$ glacioeustatic low-stand of MIS 2, the maximum glacioeustatic low-stands associated with MIS 6, 8, 10, and 12 were 111, 92, 98, and 
Table 1

Chronostratigraphic control for VENICE-1 drill core composite

\begin{tabular}{|c|c|c|c|c|}
\hline Stratigraphic event & Depth in core $(\mathrm{m})$ & Agel (Ma) & Age2 (Ma) & References for Age1 (Age2) \\
\hline $\operatorname{tr} .1$ & 10.5 & 0.011 & & 〜 MIS 1/2: Shackleton (1995) \\
\hline $\operatorname{tr} .2$ & 79.0 & 0.125 & & 〜 MIS 5/6: Shackleton (1995) \\
\hline $\operatorname{tr} .3$ & 136.0 & 0.220 & $(0.175)$ & $\sim \operatorname{MIS} 7.3 / 7.4(\sim \operatorname{MIS} 6.1 / 6.2)$ : Shackleton (1995) \\
\hline $\operatorname{tr} .4$ & 152.0 & 0.245 & $(0.200)$ & $\sim \operatorname{MIS} 7 / 8(\sim \operatorname{MIS} 7.1 / 7.2):$ Shackleton (1995) \\
\hline $\operatorname{tr} .5$ & 202.0 & 0.340 & $(0.225)$ & $\sim \operatorname{MIS} 9 / 10(\sim \operatorname{MIS} 7.3 / 7.4):$ Shackleton (1995) \\
\hline $\operatorname{tr} .6$ & 262.0 & 0.430 & $(0.250)$ & $\sim \operatorname{MIS~11/12~(~MIS~7/8):~Shackleton~(1995)~}$ \\
\hline sapropel VS 01 & 558.9 & 0.529 & $(0.407)$ & Sa (S11); Langereis et al. (1997) \\
\hline P. lacunosa $\mathrm{HO}$ & 561.4 & & $(0.440)$ & (LAD): Langereis et al. (1997) \\
\hline Gephyrocapsa sp. $3 \mathrm{HO}$ & 571.5 & 0.577 & & LAD: Langereis et al. (1997) \\
\hline sapropel VS 02 & 572.4 & 0.597 & & Sb: Langereis et al. (1997) \\
\hline Brunhes/Matuyama & 727.8 & 0.783 & & C1n/1r: Cande and Kent (1995) \\
\hline Gephyrocapsa sp. 3 LO & 755.8 & 0.957 & & FAD: Langereis et al. (1997) \\
\hline Jaramillo, top & $?$ & 0.990 & & C1r.1n end: Cande and Kent (1995) \\
\hline Jaramillo, base & $?$ & 1.070 & & C1r.1n begin: Cande and Kent (1995) \\
\hline Large Gephyrocapsa $\mathrm{HO}$ & 779.92 & 1.238 & & LAD: Rio et al. (1996) \\
\hline N. pachyderma sin. & 784.21 & 1.367 & & LAD: Rio et al. (1996) \\
\hline Large Gephyrocapsa LO & 799.46 & 1.608 & & FAD: Rio et al. (1996) \\
\hline G. oceanica s.1. LO & 809.11 & 1.710 & & FAD: Rio et al. (1996) \\
\hline Olduvai, top & $?$ & 1.785 & & C2n end: Cande and Kent (1995) \\
\hline Olduvai, base & $?$ & 1.942 & & C2n begin: Cande and Kent (1995) \\
\hline unconformity (end) & 813.0 & $\sim 1.810$ & & \\
\hline unconformity (begin) & 813.0 & $\sim 2.400$ & & \\
\hline Matuyama/Gauss & 887.2 & 2.581 & & C2r/2An: Cande and Kent (1995) \\
\hline Base of core & 949.0 & $\sim 2.680$ & & \\
\hline
\end{tabular}

$\mathrm{HO}=$ Highest Occurrence, LO = Lowest Occurrence. Age1 is Age Model 1, (Age2) is Age Model 2 (see text). Depths are given according to labels on the cores; $3.2 \mathrm{~m}$ should be subtracted from depths in VE-1 (tr.2 and deeper events) for registry to depths in vE BIS (tr.1 event).

$110 \mathrm{~m}$, respectively (Fig. 4a). As a first approximation, the initial continental deposits at $289 \mathrm{~m}$ should correspond to one of these glacioeustatic low-stands. However, even after isostatic correction (to $194 \mathrm{~m}$ ), the depth of the first continental sediments is at least $73 \mathrm{~m}$ and as much as $102 \mathrm{~m}$ in excess of these maximum glacioeustatic low-stands. If the initial emergence occurred at the oldest permissible major low-stand of Age Model 1 (MIS 12 at around $0.425 \mathrm{Ma}$ ), this would indicate an average subsidence rate of approximately $180 \mathrm{~m} / \mathrm{m}$.y. to accommodate the isostatically compensated thickness of overlying sediment. If it occurred at the youngest permissible major low-stand of Age Model 2 (MIS 8 at around $0.250 \mathrm{Ma}$ ), an average subsidence rate of about $360 \mathrm{~m} / \mathrm{m} . \mathrm{y}$. is indicated.

The relative elevation of continental sediments in the ancient topography is difficult to specify. However, transgression surfaces tr. 1 to tr. 6 provide unambiguous evidence of relative sea level which must have passed through zero water depth at each of these levels. The average rate of subsidence can thus be estimated by fitting these transgression surfaces to the known sequence of major glacioeustatic increases. A linear subsidence rate of $180 \mathrm{~m} / \mathrm{m}$.y from Age Model 1 was found to produce a neat match to the glacioeustatic reference curve: tr. 6 to MIS11/12, tr. 5 to MIS $9 / 10$, tr. 4 to MIS7/8, and tr.3 to MIS 7.1/7.2 (as well as Tr.2 to MIS5/6 and tr.1 to MIS1/2 as already suggested by pollen (Mullenders et al., 1996) and radiocarbon data (Bortolami et al., 1985, 1977) (Fig. 4b). This model suggests that the highest recorded occurrence of $P$. lacunosa in VENICE-1 may be too low in the section due to poor preservation and thus simply gives a minimum age constraint.

Age Model 2 that matches tr.6 to the MIS 7/8 transition $(\sim 0.250 \mathrm{Ma})$ allows the $P$. lacunosa $\mathrm{HO}$ to be a true datum. However, this young end-member model requires an irregular pattern of subsidence because there are too few major glacioeustatic features in the reference curve to match all the transgressions (Fig. 4c). In particular, the need to match tr.3 with a relatively minor glacioeustatic rise requires an abrupt large departure centered at around $0.175 \mathrm{Ma}$ from the mean subsidence rate of $360 \mathrm{~m} / \mathrm{m} . \mathrm{y}$. to accommodate the zero water-depth constraints. In the absence of independent evidence for tectonic activity in the Venice area that could account for such large changes in subsidence in the Late Pleistocene required by Age Model 2, the simple linear subsidence of Age Model 1 provides a more parsimonious solution.

\section{Sea level fluctuations}

A sea-level curve for the Venice area was constructed by taking the difference between the glacioeustatic 


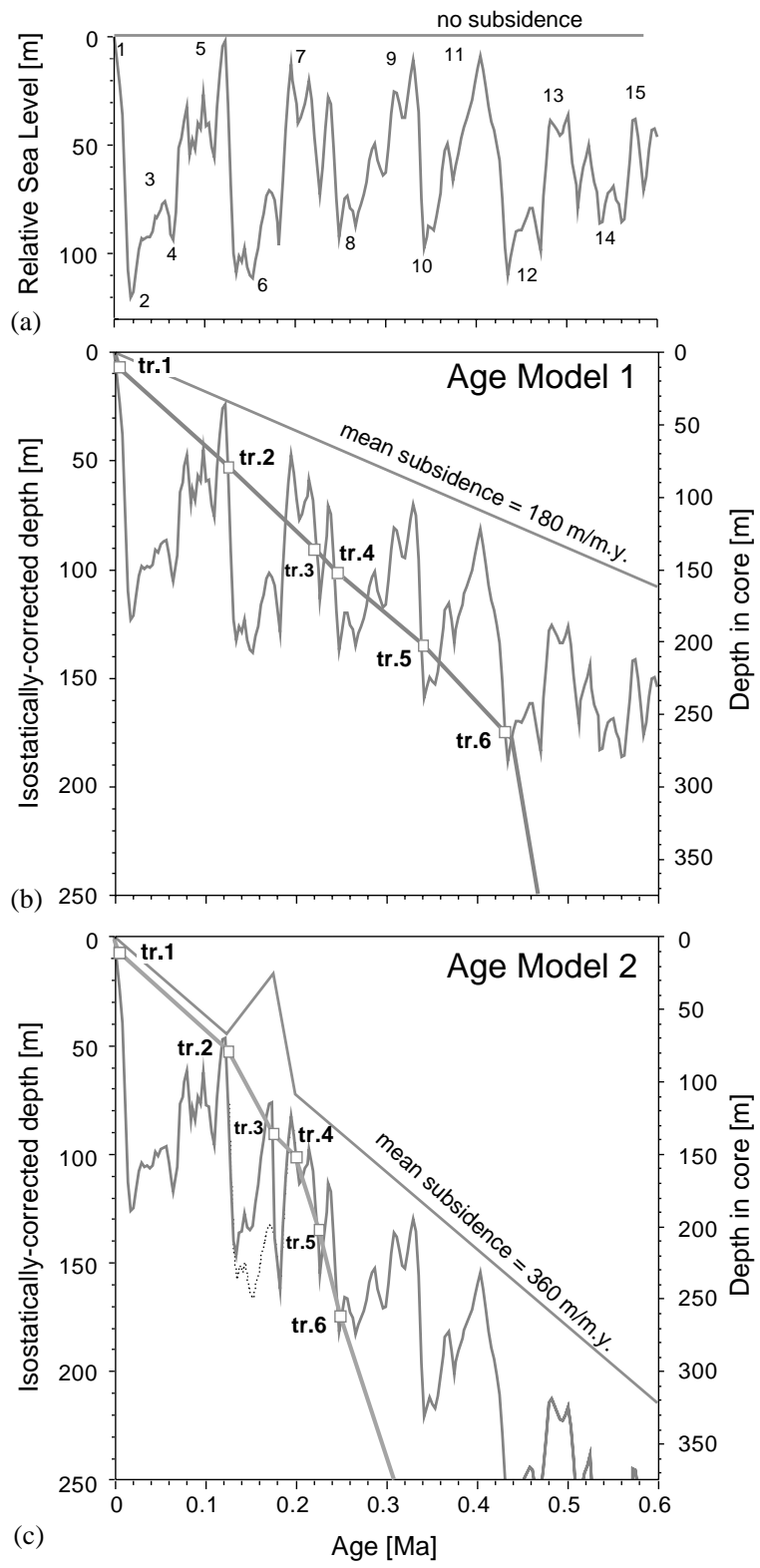

Fig. 4. (a) Reference glacioeustatic curve obtained by scaling the ODP Site 677/SPECMAP oxygen isotope curve (Shackleton, 1995) to the $120 \mathrm{~m}$ glacioeustatic decrease at Last Glacial Maximum in Barbados (Fairbanks, 1989). Key marine isotope stages (MIS) labeled from 1 to 15. (b) Match of zero-water depth transgression surfaces tr.1 to tr.6 to the glacioeustatic reference curve using Age Model 1 and a linear subsidence rate of $180 \mathrm{~m} / \mathrm{m} . \mathrm{y}$. (c) Match of tr. 1 to tr.6 to the glacioeustatic reference curve using Age Model 2 and an average subsidence rate of $360 \mathrm{~m} / \mathrm{m}$.y. with a large adjustment (shown by dotted curve segment) needed to match tr.3 with a relatively minor glacioeustatic rise in MIS 6.

reference curve adjusted for long-term subsidence and the linked sediment accumulation curve for VENICE-1 according to Age Model 1. The resulting sea-level record (Fig. 5) shows maximum water depths of around $300 \mathrm{~m}$ during glacioeustatic high-stands at around the Brunhes/Matuyama boundary (e.g., MIS 19), shoaling over the early Brunhes with rapid deltaic sedimentation,

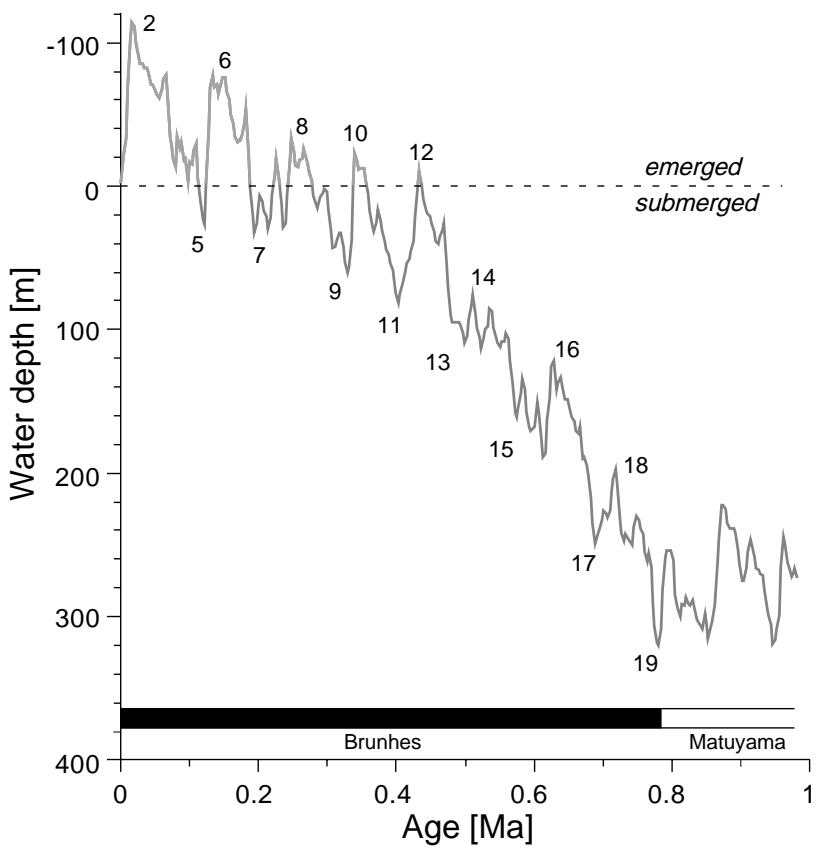

Fig. 5. Elevation of the Venice area with respect to modern sea level since $\sim 1$ Ma calculated by taking the difference between isostatically adjusted depths in VENICE-1 and the glacioeustatic reference curve using Age Model 1.

and the first emergence of the Venice area above sea level in MIS $12(\sim 0.435 \mathrm{Ma})$. As the basin continued to fill with marine and continental sediments, the Venice area rose to higher elevations during subsequent major glacioeustatic low-stands and became submerged to progressively shallower water depths during the intervening major glacioeustatic high-stands. These interrelated trends culminated when the Venice area stood at an elevation of approximately $120 \mathrm{~m}$ above sea-level during the LGM (MIS 2, 18,000 years ago) and now some areas of Venice have stayed emergent even during a major glacioeustatic high-stand (Holocene or MIS 1).

The total long-term subsidence rate estimated from the VENICE-1 record ranges from 240 to $480 \mathrm{~m} / \mathrm{m}$.y (or 0.24 to $0.48 \mathrm{~mm} / \mathrm{yr}$ ) without isostatic correction. Linear regression on porosity data for VENICE-1 sediments (CNR, 1971) shows considerable scatter around a mean porosity of around $40 \%$ with only a negligible trend of a few percent over the entire length of the core. The absence of an obvious overall decrease in porosity with depth suggests that natural compaction in these sediments, which include acquifers (Gatto and Carbognin, 1981), is not a major factor in long-term subsidence which must therefore reflect mainly tectonic processes. This conclusion receives support from the modeling studies by Negredo et al. (1997) who estimated subsidence rates of about $0.3 \mathrm{~mm} / \mathrm{yr}$ due to the effects of active tectonics in the distal northern Adriatic region.

Whatever the exact mechanisms and age model, the total long-term subsidence was less than $0.5 \mathrm{~mm} / \mathrm{yr}$, well 
below the subsidence rate of $1.3 \mathrm{~mm} / \mathrm{yr}$ determined by radiocarbon dating for the latest Pleistocene and Holocene of the Venice lagoon (Bortolami et al., 1977, 1985; Gatto and Carbognin, 1981). The higher latest Pleistocene and Holocene subsidence rate most likely reflects consolidation of sediments over the initial few millennia after deposition (see also Carminati and Di Donato, 1999). From a geological perspective, parts of the Venice area are emergent today because the net accumulation of continental sediments over the Late Pleistocene has more than compensated for any erosion, tectonic subsidence, and sediment compaction during the Holocene glacioeustatic high-stand. Of more immediate concern to the watery fate of Venice (e.g., (Ammerman and McClennen, 2000) is sinking that averaged about $3 \mathrm{~mm} / \mathrm{yr}$ due to withdrawal of groundwater over several decades of the 20th century (Gatto and Carbognin, 1981; Carbognin et al., 1995) as well as the ongoing eustatic rise of $1-2 \mathrm{~mm} / \mathrm{yr}$ according to the latest estimates from the IPCC Third Assessment Report "Climate Change 2001". The total rate of sea level rise relative to Venice implied by these values is about an order of magnitude greater than the background subsidence rate calculated from the geologic record.

\section{Acknowledgements}

We are indebted to the staff of the "Centro C.N.R. per lo Studio della Dinamica delle Grandi Masse", particularly Laura Carbognin, Rossana Serandrei and the technicians of the Institute, for core curation and access to the repository, and to the late Franco Dalla Porta, previous Director of the CNRDGM, for his most helpful attitude in supporting our project. We thank Wout Krijgsman and Marie-Pierre Aubry for constructive comments on the manuscript and Simon Crowhurst and Nick Shackleton for providing us a digital listing of the SPECMAP/ODP 677 data. Lamont-Doherty Earth Observatory contribution \#6264.

\section{References}

Ammerman, A.J., McClennen, C.E., 2000. Saving Venice. Science 289, 1301-1302.

Bellet, J., Oudin, J.-L., Favero, V., Passega, R., 1982. Analyse optique de la matière organique du Quaternaire: Sondage CNR VE-1, Venise. Revue de l'Institut Francais du Petrole 37, 587-598.

Boccaletti, M., Calamita, F., Deiana, G., Gelati, R., Massari, F., Moratti, G., Ricci Lucchi, F., 1990. Migrating foredeep-thrust belt system in the northern Apennines and southern Alps. Paleogeography, Paleoclimatology, Paleoecology 77, 3-14.

Bortolami, G., Carbognin, L., Gatto, P., 1985. The natural subsidence in the lagoon of Venice, Italy. IAHS Publication 151, 777-784.

Bortolami, G.C., Fontes, J.C., Markgraf, V., Saliege, J.F., 1977. Land, sea and climate in the Northern Adriatic region during Late
Pleistocene and Holocene. Palaeogeography, Palaeoclimatology, Palaeoecology 21, 139-156.

CNR, 1971. Relazione sul pozzo Venezia 1-CNR. 1a fase:Operazioni di cantiere eanalisi delle carote. Laboratorio Dinamica Grandi Masse, Consiglio Nazionale delle Richerche, Venice.

Cande, S.C., Kent, D.V., 1995. Revised calibration of the geomagnetic polarity time scale for the Late Cretaceous and Cenozoic. Journal of Geophysical Research 100, 6093-6095.

Carbognin, L., Marabini, F., Tosi, L., 1995. Land subsidence and degradation of the Venice littoral zone, Italy. In: Proceedings of the Fifth International Symposium on Land Subsidence. Hague, pp. 391-402.

Carminati, E., Di Donato, G., 1999. Separating natural and anthropogenic vertical movements in fast subsiding areas: the Po plain. Geophysical Research Letters 26, 2291-2294.

de Beaulieu, J.-L., Eicher, U., Monjuvent, G., 1994. Reconstruction of Middle Pleistocene palaeoenvironments based on pollen and stable isotope investigations at Val-de-Lans, Isere, France. Vegetation History and Archeobotany 3, 127-142.

Fairbanks, R.G., 1989. A 17, 000-year glacio-eustatic sea level record: influence of glacial melting rates on the Younger Dryas event and deep-ocean circulation. Nature 342, 637-642.

Favero, V., Alberotanza, L., Barbero, S.R., 1973. Aspetti paleoecologici, sedimentologici e geochimici dei sedimenti attraversati dal pozzo VE 1 bis C.N.R., Consiglio Nazionale delle Richerche, Venezi. p. 51.

Follieri, M., Magri, D., Sadori, L., 1988. 25,000 year pollen record from Valle di Castiglione (Roma). Pollen et Spores 30, 329-356.

Gatto, P., Carbognin, L., 1981. The Lagoon of Venice: natural environmental trend and man-induced modification. Hydrological Sciences Bulletin 26, 379-391.

Kukla, G., Heller, F., Ming, L.X., Chun, S.T., Shen, L.T., Sheng, A.Z., 1988. Pleistocene climates in China dated by magnetic susceptibility. Geology 16, 811-814.

Langereis, C.G., Dekkers, M.J., de Lange, G.J., Paterne, M., van Santvoort, P.J.M., 1997. Magnetostratigraphy and astronomical calibration of the last $1.1 \mathrm{Myr}$ from an eastern Mediterranean piston core and dating of short events in the Brunhes. Geophysical Journal International 129, 75-94.

Lowrie, W., 1990. Identification of ferromagnetic minerals in a rock by coercivity and unblocking temperature properties. Geophysical Research Letters 17, 159-162.

Mullenders, W., Favero, V., Coremans, M., Dirickx, M., 1996. Analyses polliniques de sondages a Venise (VE-I, VE-I BIS, VEII). Aardkundige Mededelingen 7, 87-117.

Negredo, A.M., Sabadini, R., Giunchi, C., 1997. Interplay between subduction and continental convergence: a three-dimensional dynamic model for the central Mediterranean. Geophysical Journal International 131, F9-F13.

Parker, F. L. (1958). Eastern Mediterranean Foraminifera. Report of the Swedish Deep Sea Expedition 1947-48, Vol. 8, pp. 217-283.

Pirazzoli, P.A., 1977. Quaternary deep cores from the Venice area (Italy). In: Horie, S. (Ed.), Paleolimnology of Lake Biwa and the Japanese Pleistocene. Omi-Takashima, Tokyo, pp. 27-287.

Reille, M., Andrieu, V., de Beaulieu, J.-L., Guenet, P., Goeury, C., 1998. A long pollen record from Lac du Bouchet, Massif Central, France: For the period ca. 325 to $100 \mathrm{ka}$ BP (OIS 9c to OIS 5e) Quaternary Science Reviews 17, 1107-1123.

Reille, M., de Beaulieu, J.-L., 1995. Long Pleistocene pollen records from the Praclaux Crater, south-central France. Quaternary Research 44, 205-215.

Rio, D., Channell, J.E.T., Bertoldi, R., Poli, M.S., Vergerio, P.P., Raffi, I., Sprovieri, R., Thunell, R.C., 1997. Pliocene sapropels in the northern Adriatic area: chronology and paleoenvironmental significance. Palaeogeography, Palaeoclimatology, Palaeoecology $135,1-25$. 
Rio, D., Channell, J.E.T., Massari, F., Poli, M.S., Sgavetti, M., D’Alessandro, A., Prosser, G., 1996. Reading Pleistocene eustasy in a tectonicallly active siliciclastic shelf setting (Crotone peninsula, southern Italy). Geology 24, 743-746.

Robinson, S.G., 1986. The late Pleistocene palaeoclimatic record of North Atlantic deep-sea sediments revealed by mineral-magnetic measurements. Physics of the Earth and Planetary Interiors 42, 22-47.

Sclater, J.G., Christie, P.A.F., 1980. Continental stretching: an explanation of the post-mid-cretaceous subsidence of the central North Sea Basin. Journal of Geophysical Research 85, 3711-3739.

Shackleton, N.J., 1995. New data on the evolution of Pliocene climate variability. In: Vrba, E., Denton, G.H., Partridge, T.C., Burckle,
L.H. (Eds.), Palaeoclimate and evolution, with emphasis on human origins. Yale University Press, New Haven, pp. 242-248.

Tzedakis, P.C., Andrieu, V., de Beaulieu, J.L., Crowhurst, S., Follieri, M., Hooghiemstra, H., Magri, D., Reille, M., Sadori, L., Shackleton, N.J., Wijmstra, T.A., 1997. Comparison of terrestrial and marine records of changing climate of the last 500,000 years. Earth and Planetary Science Letters 150, 171-176.

Urban, B., 1992. Interglacial/Glacial transitions recorded from Middle and Young Pleistocene sections of eastern Lower Saxony, Germany. In: Kukla, G., Went, E. (Eds.), Start of a Glacial. Springer, Berlin, pp. 38-50.

Zagwijn, W.H., 1989. The beginning of the ice age in Europe and its major subdivisions. Quaternary Science Reviews 11, 583-591. 